\title{
DESIGNING AN ENGLISH SYLLABUS FOR TEACHERS OF biMBA AIUEO
}

Siti Tuti Alawiyah

English Department, Faculty of Letters, Universitas Nasional

tuti.alawiyah.sta@gmail.com

\begin{abstract}
Nowadays, the numbers of pre-schools (Pendidikan Anak Usia Dini) which is established by Rukun Tetangga in society and also established by foundation or personal are getting increased. In a such condition, it makes parents think to deliver their kids to study in a pre-school that provides English Curriculum. Therefore, school foundation always tries hard in order to be the best school which has English lesson. At first, biMBA (bimbingan minat baca anak) only provides calistung program (baca tulis hitung). Due to the request from parents and the reality that many pre-schools have provided English subject, Mitra (who manage) biMBA decided to open English class in biMBA. Unfortunately, many teachers at biMBA AIUEO do not have English background. It can be assumed that they might produce mistakes and errors in pronunciation and spelling. That is why, English course is necessary to improve their English skills mainly at pronunciation and spelling. Before designing the course, needs analysis should be conducted in order to know what teachers need during the course later. The steps will be begun through distributing questionnaires to the teachers and an interview with their Mitra to obtain more insights about teacher's knowledge. Afterwards, the results of the needs analysis will be interpreted to design a syllabus for them. It is believed that the syllabus based on learner's needs will be more effective, and the learners's goal to learn English can be achieved as well.

Keywords: Teachers biMBA AIUEO, ESP, Needs Analysis, Present Situation Analysis (PSA), Learning Situation Analysis (LSA), Target Situation Analysis, Syllabus
\end{abstract}

\begin{abstract}
ABSTRAK
Saat ini, jumlah PAUD (Pendidikan Anak Usia Dini) yang didirikan oleh Rukun Tetangga dalam masyarakat dan juga didirikan oleh yayasan atau pribadi semakin meningkat. Kondisi seperti itu membuat orang tua berpikir untuk memasukkan anak-anak mereka untuk belajar di PAUD yang menyediakan kurikulum Bahasa Inggris. Oleh karena itu, yayasan sekolah selalu berusaha keras untuk menjadi sekolah terbaik yang menyajikan pelajaran bahasa Inggris. Pada awalnya, biMBA (bimbingan minat baca anak) hanya menyediakan program calistung (membaca, menulis dan menghitung). Karena permintaan dari orang tua dan kenyataan bahwa banyak PAUD menyediakan pelajaran bahasa Inggris, Mitra (pihak yang mengelola) biMBA memutuskan untuk membuka kelas bahasa Inggris di biMBA. Sayangnya, banyak guru yang mengajar di biMBA AIUEO tidak memiliki latar belakang bahasa Inggris. Dapat diasumsikan bahwa mereka mungkin akan melakukan kesalahan dalam pengucapan dan ejaan. Itu sebabnya kursus bahasa Inggris sangat diperlukan untuk meningkatkan kemampuan bahasa Inggris guru-guru tersebut, terutama dalam hal pengucapan dan ejaan. Sebelum merancang kursus, analisis kebutuhan (needs analysis) harus dilakukan untuk mengetahui apa yang guru harus lakukan selama kursus nanti. Penelitian dimulai dengan penyebaran kuesioner untuk para guru dan wawancara dengan Mitra untuk mendapatkan wawasan lebih tentang pengetahuan Bahasa Inggris para guru. Setelah itu, hasil analisis kebutuhan akan ditafsirkan untuk merancang silabus. Silabus yang dibuat berdasarkan kebutuhan peserta didik dipercaya lebih efektif, dan tujuan peserta didik untuk belajar bahasa Inggris dapat diraih.
\end{abstract}

Kata Kunci: guru-guru di biMBA AIUEO, ESP, analisis kebutuhan (needs analysis), Present Situation Analysis (PSA), Learning Situation Analysis (LSA), Target Situation Analysis, silabus

\section{INTRODUCTION}

The existence of pre schools in Indonesia are getting increased. It because children population that always raise every year. Another reason is parents are very happy to deliver their children for school. They want their children have fun learning at school. By considering those factors the government provides schools that is known
PAUD (Pendidikan Anak Usia Dini) which is free for kids three to five years old. Beside government, there are many private pre schools (managed by personal or foundation). One of them is biMBA AIUEO unit $\mathrm{gg}$. Nangka, Depok. biMBA is an instution which is managed under YPAI (Yayasan Pendidikan Anak Indonesia). The institution gave the opportunities to public who want to open biMBA by purchasing biMBA's franchise 
license. In short, Mitra (a person who has biMBA's license) has right to develop biMBA including open English class.

In biMBA, children only learning calistung (baca tulis hitung). As requested from parents to open English class and see the competitiveness in schools that provide English class, Mitra biMBA AIUEO thought that English class is necessary to provide in her Unit.

Unfortunately, the teachers have not English background, so there is a possibility that they produce mistakes and error especially in pronunciation or spelling, that is why Mitra wants the teachers take an English course before they start teaching English for their students.

In addition, the present situation shows that parents are very critical to what teachers give in class and they are courageous as well to express their objection if they see the school as the second home for their children is not as expected as they want. Most of parents now are smart and many of them are familiar with English. It will give bad image for school if the school opens English class but the teachers do not know about English.

In brief, the writer would like to contribute to the teachers by conducting English course to improve their pronunciation skill and spelling. I have told my intention to school and they agree to particapate in the course. They hope, it can give postive influences to themselves learning English especially they know how to pronounce a single word correctly and able to write sentences well.

Teaching for particular occupation such a teacher who comes from non English department is certainly different. In this case English for Occupational Purposes (EOP) as a branch of English for Specific Purposes is more apropriate to apply. According to Edward (2000) as stated in Al Khatib (2005), said "There is a correlation between the place of work and the effective needs of workers in terms of language skills practiced, terminology used, and syllabus design, and material preparation for the workers." Absolutely, ESP must be different from English for General Purposes (Dudley Evan \& St. John 1998). Syllabus becomes an important element for teacher that wiil deliver English at particular class. In this case, the writer will carry out English course for teachers at biMBA AIUEO, Tapos Depok.

Before carrying out the course, the writer will design a syllabus frstly. To have a fruitful syllabus and in order to achieve best result, the writer as a course developer should conduct needs analysis. It is necessary to show the teacher's recent situation, target situation, and learning situation. Since the syllabus is based on learners' needs, it is likely to be motivating for learners, who see the obvious relevance of what they are studying (Basturkmen, 2006). In conducting the ESP class, the course developer should concern with the materials and the methodology of teaching and those should be adjusted to their competence. Therefore, ESP must be based on the principle of effective and efficient learning (Dudley Evan \& St. John, 1998).

As I mentioned above, parents expect that biMBA provides English class, but the available teachers have no English background. Hence, there is a possibility that teachers might produce mistake and error in pronouncing and spelling English. Mitra biMBA admitted that to fulfill the parents' expectation to open English class she required her teachers to participate in English course.

Before delivering the course, firstly the writer should make an appropriate syllabus. In order to design the most appropriate syllabus, a cereful study on the needs of the learners and school party have to be carried out. Nunan \& Carter (2004, p. 224) defined needs analysis as an "analysis conducted to determine what learners needs to be able to do in English in their educational or professional situation". Based on the description above, the research questions that have to be addressed in this study are:

1) What are the needs of biMBA AIUEO Teachers in learning English?

2) What kind of syllabus design is appropriate to improve the English pronunciation, spelling, and the language knowledge of teachers roommate?

The aim of this study is to seek the needs of the biMBA AIUEO teachers to improve their English knowledge especially in pronouncing and spelling in English, so they can minimize mispronouncing or misspelling when they are teaching English. In addition, the objective of 
this study is to search for the learning and target situation of the learners in order to make them perform better in the target situation. To achieve those aims, the writer will develop a suitable syllabus for the teachers.

\section{LITERATURE REVIEW}

\section{English for Specific Purposes/ESP}

Creating a syllabus is not as simple as teaching. Anyone can make a syllabus and teach the material. But, whether the syllabus is suitable or not for the learners, if it is suitable of course the goal wil be achieved easily as most of students will enjoy the learning process, they will acquire the language easier. Hence, needs analysis is necessary to carry out their needs in learning English. In this study, the writer is going to propose a course syllabus to Mitra biMBA. As the final target of the course the teachers are expected understand English knowledge, and able to pronounce and spell English words very well.

Dudley-Evans \& St. John's (1998:45) argues that ESP should focus on profession or disciplines because it is different from general English. They specify two characteristics in ESP namely, absolute characteristic and variable characteristic as follows:

1. Absolute characteristics:

a. ESP is designed to meet specific needs of the learner;

b. ESP makes use of the underlying methodology and activities of the disciplines it serves;

c. ESP is centered on the language grammar, lexis, register, skills, discourse and genres appropriate to these activities.

2. Variable characteristics:

a. ESP may be related to or designed for specific disciplines;

b. ESP may use, in specific teaching situations, a different methodology than that of general English.

c. ESP is likely to be designed for adult learners, either at a tertiary level institution or in a professional work situation. It could, however, be used for learners at secondary school level; d. ESP is generally designed for intermediate or advanced students. Most ESP courses assume basic knowledge of the language system, but it can be used with beginners.

The absolute and variable characteristics above distinguish ESP's features and General English's.

In summary, learners of ESP are willing to study English because they want to perform convincingly as required in real practice. That is why ESP course should be designed to fulfill the learner's needs and it should be designed specifically in terms of differences in the selection of skills, topics, situations, functions and language level. In order to achieve the best result in its implementation, ESP teachers or course developers need to find out what the language based objectives of the students are in the target occupation or academic disciplines and ensure that the content of the ESP course works toward them (Basturkmen, 2006).

\section{Needs Analysis}

According to Hutchinson and Waters (1992), learners know specifically why they are learning a language and it is the awareness of a need that ESP distinguishes for. Thus, they see students' needs analysis as a keypoint in the development of an ESP course as this approach of language learning is student centered.

\section{Approaches to needs analysis}

Present Situation Analysis (PSA), Learning Situation Analysis (LSA), and Target Situation Analysis (TSA) are the approaches that are carried out in needs analysis. A course designer should utilize them because the approaches provide useful information and assist her/ him to get better understanding about the real situation of the language learner. As stated by Dudley-Evans \& St John (1998, p.125), “A Present Situation Analysis estimates strengths and weaknesses in language, skills, and learning experiences".

According to Dudley-Evans \& St John (1998, pp.123-124) "Target Situation Analysis (TSA) investigates the objective and perceived needs derived by outsiders from facts, from what is known, and can be verified". It is important to know what learners expect to learn at the end of the course, which is related to the language use 
and what kind of tasks and activities the learners will be using English for during the course.

The last approach is the Learning Situation Analysis (LSA). It concerns with learners' situation, subjective and felt needs of how the learning situation based on learner preference in their learning process and learning styles (Dudley-Evans and St John (1998, p.124). Hutchinson and Waters (1993, pp. 59-63) use WH questions while analyzing the target situation and the learning needs as well.

\section{RESEARCH METHOD}

There are six methods of main data collection for needs analysis proposed by Dudley-Evans and St. John (1998). They are questionnaires, analysis of authentic spoken and written texts, discussions, structured interviews, observations and assessments. In this study, questionnaires and structured interviews were used to conduct needs analyis.

\section{Syllabus and Types of syllabus}

In general, a syllabus can be defined as a framework of a course which comprises information and the objectives in every meeting are described more detailed and specifically. It is also a part of curriculum and it assists teachers and students to focus more on a particular topic. Candlin (1984, p.31, in Rahimpour, 2010, p.1660) defines a curriculum as follows, "Curriculum is concerned with making general statements about language learning, learning purpose, experience, evaluation, and the role and relationship of teachers and learners. Syllabuses are more localized and are based on accounts and records of what actually happens at the classroom level as teachers and learners apply a given curriculum to their own situation (narrower definition)."

Meanwhile, Yalden (1991, pp. 92-93) allows the syllabus designer to use one or more syllabi to cover weaknesses of one syllabus with strong points from another syllabus. To design a syllabus there are some steps suggested by Yalden as follows:
Figure 1. Framework of Designing a Syllabus (Yalden, 1991, p.93)

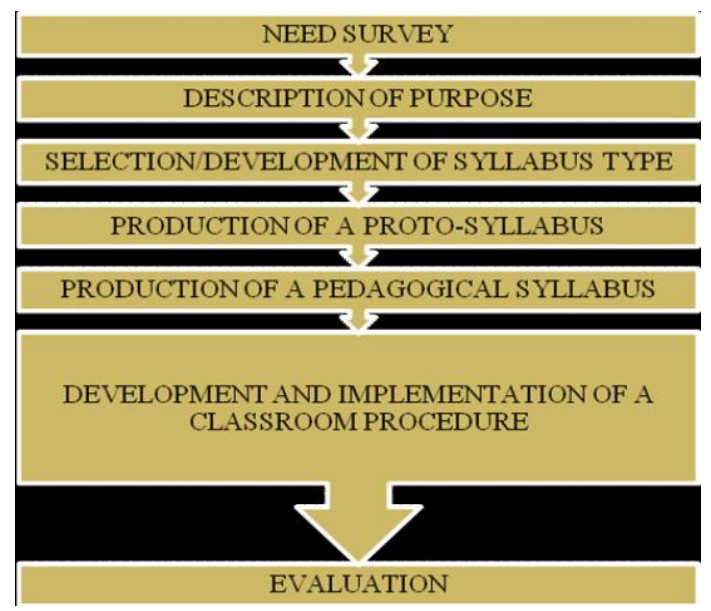

\section{Types of syllabus}

There are several types of syllabus of ESP class are proposed by the scholars. According to Krahnke (1987), there are six types of syllabus in language teaching. These different types of syllabuses rarely stay independent because actually they are not entirely distinct from one another. The syllabuses are structural (formal) syllabus, notional/functional syllabus, situational syllabus, skill-based syllabus, task based syllabus, and content based syllabus.

Even though the above syllabi have been explained clearly with its own strengths and weaknesses, but for some teachers it is still difficult to choose which one of the syllabi is the best one to be applied in their EOP class. Based on that reason, Yalden (1991, p.93) proposed another type of syllabus, namely proportional syllabus. This syllabus is a combination of two or more syllabi. It means, the teacher or course designer is allowed to produce a proportional syllabus by combining one syllabus with another syllabus.

\section{Data Collection Procedures}

In doing needs analysis, the syllabus designer should pay attention to approaches such as PSA (present situation analysis), TSA (target situation analysis), and LSA (learning situation analysis). Dudley-Evans \& St. John (1998) stated that present situation describes the learners' personal information, including their purpose in learning English, their current proficiency, and any shortcomings while target situation delineates the goals after joining the course. In addition, learning situation is more what the learners like to do 
during the course. In this study those approaches that are suggested by DudleyEvans \& St. John (1998) are used. After the questionnaires are ready, the writer distributed them to all teachers then continued by interviewing teachers and Mitra.

\section{Designing a proportional syllabus}

One of the factors that make the ESP course successful is because of the syllabus.That is why the course designer should be aware in arranging the steps in the syllabus itself. In this study, Yalden's approach (Yalden, 1986, p.25) was adopted. She proposed a proportional approach in designing a syllabus. According to her, it is possible for a course designer to combine one syllabus with another syllabus as long as the weaknesses of one syllabus can cover the other one by its strong points. She further suggested some steps to design a syllabus as described in Figure 1.

\section{Data Analysis}

This study is quantitative and qualitative research. In the quantitative analysis teacher responses will be calculated to get the illustration of the participants. The quantitative data will be obtained from the information found in the questionnaires which were distributed to the teachers. A simple percentage analysis was used for the quantitative data. The highest percentage of responses from each question in the questionnaire shows what respondents chose mostly.

\section{FINDINGS AND DISCUSSION}

\section{Research Question 1: What are the needs of biMBA teachers in learning English?}

In order to know the needs of biMBA Teachers in learning English, the writer did some steps, first, wrote a questionnaire and prepared a list of questions for interview. Afterwards, the writer distributed the questionnaires to the biMBA teachers and conducted an interview with Mitra Unit and four of eight biMBA teacher at different times. The contents of questionnaire covered learners' TSA, PSA and LSA that are adapted by Dudley - Evan \& St. John's concept. The findings and discussion are a follows:

\section{Findings on present situation analysis}

The present situation analysis discussed the current situation of the biMBA teachers before the course began. The information covers the biMBA teachers working experience, the duration of using English at work, their difficulty in English skills, and their level in English skills.

\section{Using English in Working Situation}

Ability to speak English is required for the teachers who will teach English for kids in biMBA. The material will be taught are introducing colors, counting numbers, introducing Alphabet letter, introducing animal vocabularies, etc. In short, a teacher does not need to graduate from English Faculty, but she must learn English due to the work demands. It is said by Mitra Unit Gang.Nangka, that all teachers in Unit are from different majors except English. Based on the data, before the English class opened, teachers do not use English at all.

\section{Skill used in daily work}

The data shows that $50 \%$ biMBA teachers said that speaking is a skill mostly used in their daily works. The $25 \%$ of respondents stated that skills used in daily work is reading and the sampe percentage shows that listening mostly used in daily work. The Mitra Unit, however, added that the teachers should be able to sing English songs. So pronunciation and vocabulary building are necessary to learn.

\section{Difficulties in each skill}

Since many of teachers have no English background and they did not learn English for along time so $37.5 \%$ from the teachers show that reading, speaking and listening are difficult skills to learn. Based on the data that English teacher's competency show $37,5 \%$ they are weak in listening, $25 \%$ are Moderate and $37 \%$ are good. The same result at speaking competency. Pronunciation $25 \%$ are weak, $37 \%$ are moderate and $37,5 \%$ are good. At grammar competency show that $50 \%$ of them are weak, $37 \%$ are good, and $12 \%$ are moderate. For vocabulary, $37,5 \%$ of them are weak, and thes same result show that they are good, only $25 \%$ who has moderate competency in vocabulary. For reading skill, $25 \%$ are weak, $7,5 \%$ are moderate and good. Meanwhile, for writing 
show that $50 \%$ of them are good, $37,5 \%$ are moderate and $12,5 \%$ are weak.

\section{Findings on Target Situation Analysis}

$75 \%$ from teachers have reason to participate English course because they want to be able to speak english correctly with their students in class. $25 \%$ because of the requirement which is obligated by Mitra Unit where their work and $50 \%$ to develop themselves.

\section{Findings on Learning Situation Analysis}

$75 \%$ teachers prefered learning in a class room that consist of 7-10 students and $25 \%$ like learning in a classroom that consist of 3-6 students. It indicates that they want to learn English with all their friends.62,5\% wants to learn twice a week, $37,5 \%$ wants to learn once in a week. This shows that their enthusiasm in learning English. Based on questionnaire show that $62,5 \%$ they want two hours per meeting and $12,5 \%$ three hours per meeting.

In English course, the contents and activities are expected by teachers are pronunciation drill, grammar focused excercises, vocabulary focused excercises, role plays and watching video. These activities are considered very effective to improve their English competencies.

The data shows that $50 \%$ teachers prefer using media such as audio, video and whiteboard. $37,5 \%$ they want to learn using notebook and the rest using handout or books. And the last finding in learning situation analysis is correction type. $75 \%$ agree if the teachers make correction for biMBA teachers in class and $25 \%$ after class.

\section{Findings from the Interview with Mitra Unit biMBA}

In order to have detailed information about biMBA Teachers needs to learn English, besides distributing questionnaires the writer conducted interview with four teachers at different time. The face to face interview was conducted in their Unit. To avoid misunderstanding during the interview and to make the time of interview more efficient, the writer had prepared questions such as what the main jobs of biMBA teachers are, what problems that they will face when they teach their students, what the most important that you like to improve during course are, and what she expected the teacher after joining the course.

Meanwhile the result of interview with three teacher stated that they need to improve speaking skill, pronunciation drilling and grammar.

Research Questions 2: what kind of syllabus design is appropriate to improve the communication skills and the language knowledge of biMBA teachers?

Based on questionnaire and interview result and also analyzed PSA, TSA and LSA, so the syllabus which is appropriate for biMBA Teachers is proportional syllabus. The syllabus was developed by Yalden (1991, pp.92-93). In this syllabus the writer combined structural syllabus, functional syllabus and situatinal syllabus. On the next page can be seen a design syllabus which is designed by the writer.

\section{Level \\ Total hours : Eight hours \\ Schedule : Twice a week}

The syllabus for teacher at biMBA AIUEO unit, gg. Nangka 2017

\section{Session 1:}

\begin{tabular}{|c|c|c|c|c|}
\hline $\begin{array}{c}\text { Time } \\
\text { allotment }\end{array}$ & $\begin{array}{l}\text { Topic / } \\
\text { content }\end{array}$ & $\begin{array}{l}\text { Learning } \\
\text { outcomes }\end{array}$ & $\begin{array}{l}\text { Language } \\
\text { components }\end{array}$ & Class activities \\
\hline 2 hours & $\begin{array}{l}\text { 1.Introducing } \\
\text { themselves } \\
\text { 2.Pronuncia- } \\
\text { tion } \\
\text { alphabet, and } \\
\text { letter }\end{array}$ & $\begin{array}{l}\text { Structure: } \\
\text { Participants are } \\
\text { able to: } \\
\text { - use auxiliary } \\
\text { verbs (do, does, } \\
\text { is, am, are) } \\
\text { correctly }\end{array}$ & $\begin{array}{l}\text { - Auxiliary } \\
\text { verbs, i.e. is, } \\
\text { am, are, do, } \\
\text { and does } \\
\text { - Question } \\
\text { words, i.e. }\end{array}$ & $\begin{array}{l}\text { Teacher: } \\
\text { - Explains the materials } \\
\text { they are going to study } \\
\text { in the meeting } \\
\text { - Negotiate about the } \\
\text { regulation of the class } \\
\text { with the participants }\end{array}$ \\
\hline
\end{tabular}




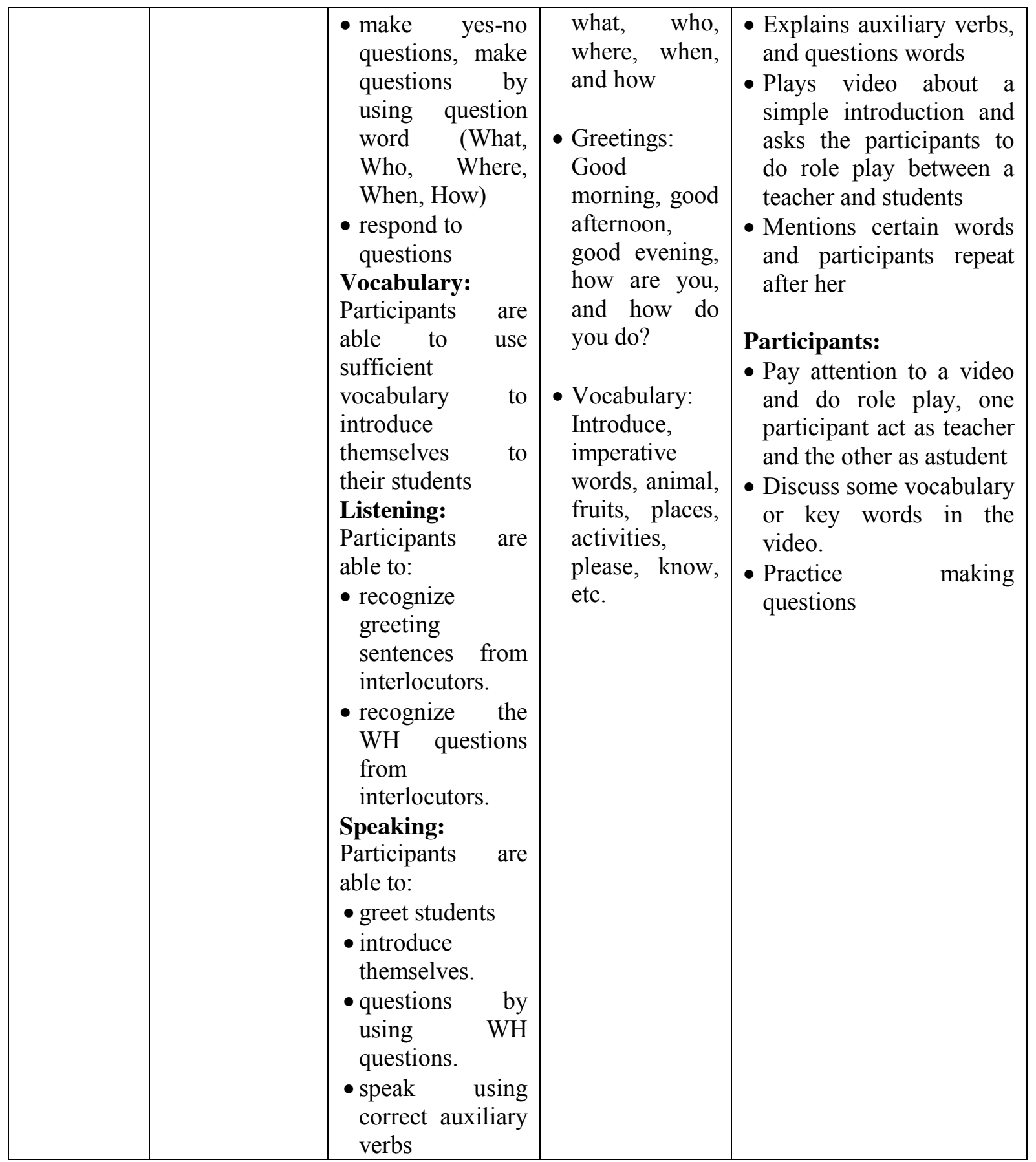

\section{Notes for the teacher:}

Based on the findings of needs analysis the participants of the course agreed the teacher corrects them during the class in front of their friends or class. However, that teacher is allowed to adjust this in accordance with what is the best for the participants.

\section{Session 2:}

\begin{tabular}{|c|c|l|l|l|}
\hline $\begin{array}{c}\text { Time } \\
\text { allotment }\end{array}$ & \multicolumn{1}{|c|}{$\begin{array}{c}\text { Topic / } \\
\text { content }\end{array}$} & \multicolumn{1}{|c|}{$\begin{array}{c}\text { Learning } \\
\text { outcomes }\end{array}$} & $\begin{array}{c}\text { Language } \\
\text { components }\end{array}$ & \multicolumn{1}{c|}{ Class activities } \\
\hline 2 hours & $\begin{array}{c}\text { 1.Review last } \\
\text { meeting }\end{array}$ & $\begin{array}{l}\text { Structure: } \\
\text { Participants are } \\
\text { 2.Introduces } \\
\text { animal, fruit, } \\
\text { places, }\end{array}$ & $\begin{array}{l}\text { Simple present } \\
\text { tenses, and } \\
\text { past tense } \\
\text { adferentiate } \\
\text { adjectives and } \\
\text { Adjective and } \\
\text { adverbs for }\end{array}$ & $\begin{array}{l}\text { Teacher: } \\
\text { Explains about adjective, } \\
\text { adverbs, simple present } \\
\text { tense, and past tense } \\
\bullet \text { Plays aviedo about }\end{array}$ \\
\hline
\end{tabular}




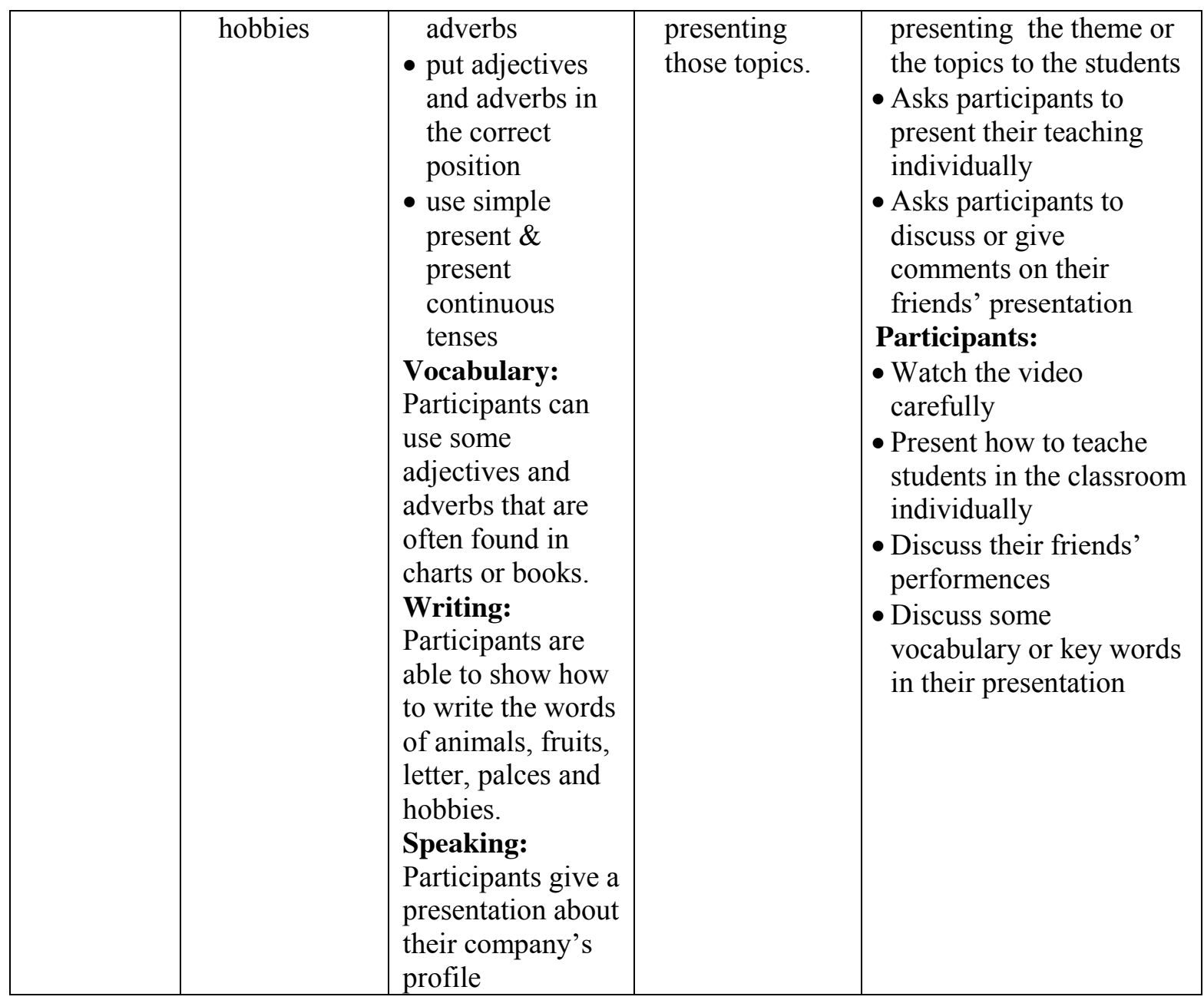

\section{Session 3:}

\begin{tabular}{|c|c|c|c|c|}
\hline $\begin{array}{c}\text { Time } \\
\text { allotment }\end{array}$ & $\begin{array}{l}\text { Topic / } \\
\text { content }\end{array}$ & $\begin{array}{l}\text { Learning } \\
\text { outcomes }\end{array}$ & $\begin{array}{c}\text { Language } \\
\text { components }\end{array}$ & Class activities \\
\hline 2 hour & $\begin{array}{l}\text { 1. Listening the } \\
\text { native } \\
\text { describing } \\
\text { the activities }\end{array}$ & $\begin{array}{l}\text { Structure: } \\
\text { Participants are } \\
\text { able to: } \\
\text { - identify the } \\
\text { correct forms of } \\
\text { verbs in present } \\
\text { continous } \\
\text { - noun phrase } \\
\text { form } \\
\text { - use countable } \\
\text { and uncountable } \\
\text { nouns } \\
\text { Vocabulary: } \\
\text { Participants are } \\
\text { able to use } \\
\text { adjectives to } \\
\text { describe the } \\
\text { specification of } \\
\text { items. i.e: big, } \\
\text { small, low, high, } \\
\text { strong, good, the } \\
\text { best, thickness, }\end{array}$ & $\begin{array}{l}\text { - Present } \\
\text { continous } \\
\text { tense and } \\
\text { perfect tense. } \\
\text { - Noun phrase } \\
\text { - Countable \& } \\
\text { uncountable } \\
\text { nouns }\end{array}$ & $\begin{array}{l}\text { Teacher: } \\
\text { - Explains present } \\
\text { continous, noun } \\
\text { phrases, and nouns } \\
\text { - Gives some texts about } \\
\text { certain topics and asks } \\
\text { participants to read } \\
\text { carefully and answer the } \\
\text { questions } \\
\text { - Plays a video in which } \\
\text { someone is describing } \\
\text { animal, fruit, places, } \\
\text { etc. } \\
\text { - Asks participants to do } \\
\text { role playa and describe } \\
\text { their own materials } \\
\text { Participants: } \\
\text { - Do role play, a teacher } \\
\text { presents his or her } \\
\text { teaching material and a }\end{array}$ \\
\hline
\end{tabular}




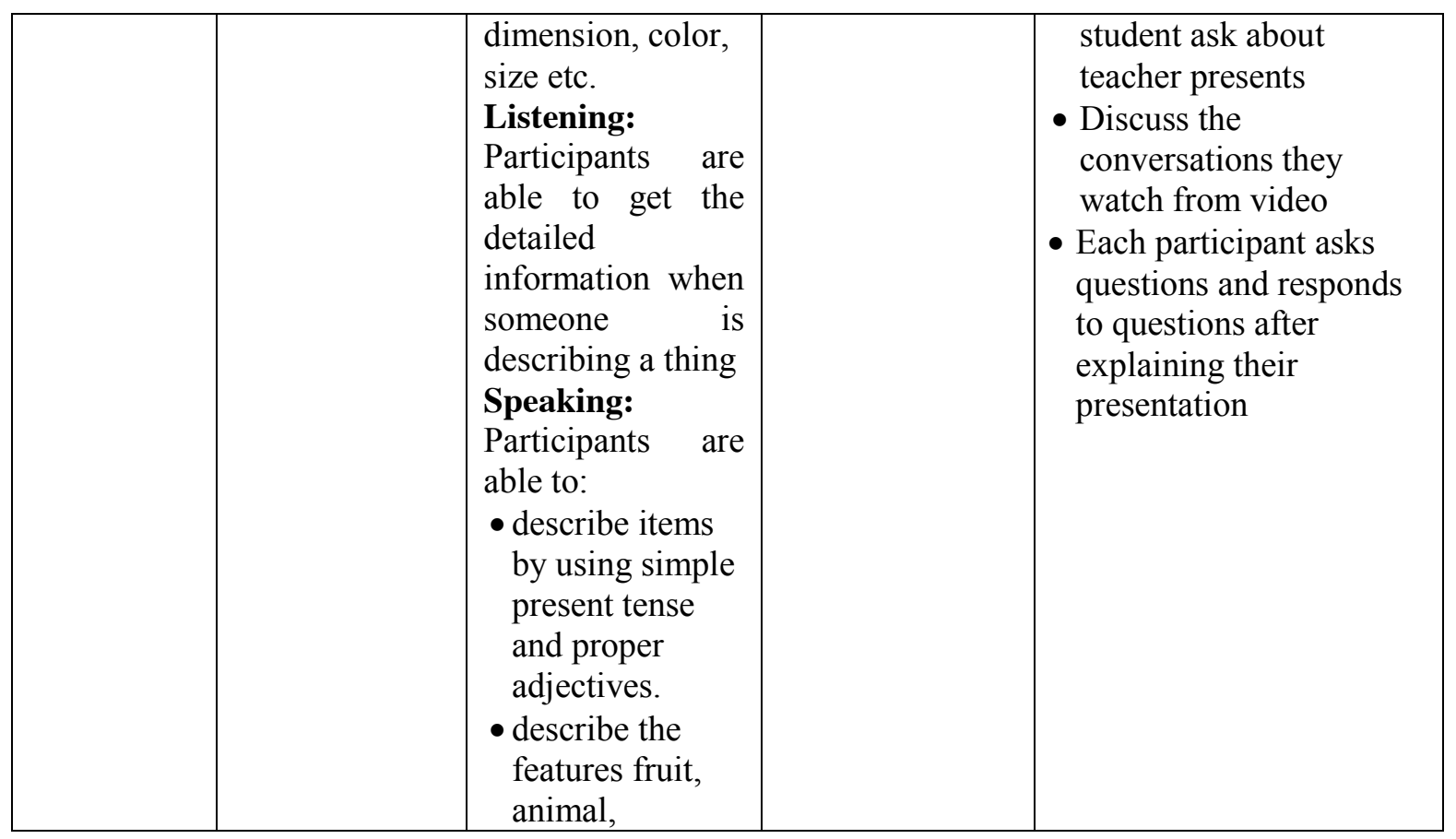

\section{Session 4:}

\begin{tabular}{|c|c|c|c|c|}
\hline $\begin{array}{c}\text { Time } \\
\text { allotment }\end{array}$ & $\begin{array}{l}\text { Topic / } \\
\text { content }\end{array}$ & $\begin{array}{l}\text { Learning } \\
\text { outcomes }\end{array}$ & $\begin{array}{l}\text { Language } \\
\text { components }\end{array}$ & Class activities \\
\hline 2 hours & $\begin{array}{l}\text { 1.Presenting } \\
\text { and } \\
\text { describing } \\
\text { Animal, } \\
\text { fruit, places } \\
\text { (part II) }\end{array}$ & $\begin{array}{l}\text { Structure: } \\
\text { The participants } \\
\text { are able to use } \\
\text { passive active } \\
\text { voices } \\
\text { Vocabulary: } \\
\text { Participants are } \\
\text { able to: } \\
\text { - use noun and } \\
\text { noun phrases } \\
\text { when describing } \\
\text { things } \\
\text { - learn more } \\
\text { adjectives for } \\
\text { describing } \\
\text { things } \\
\text { Listening: } \\
\text { Participants are } \\
\text { able to understand } \\
\text { the conversation } \\
\text { on the video. } \\
\text { Reading: } \\
\text { Participants are } \\
\text { able to: } \\
\text { - comprehend the } \\
\text { texts given. } \\
\text { - Answers the } \\
\text { questions based } \\
\text { on the texts } \\
\text { correctly }\end{array}$ & $\begin{array}{l}\text { - Passive active } \\
\text { voices } \\
\text { - Noun phrases } \\
\text { and adjectives }\end{array}$ & $\begin{array}{l}\text { Teacher: } \\
\text { - Explains passive active } \\
\text { voices } \\
\text { - Gives the texts related } \\
\text { to the topics } \\
\text { - Gives grammar and } \\
\text { vocabulary exercises } \\
\text { such as choosing the } \\
\text { right forms of verbs, } \\
\text { correct adjectives. } \\
\text { Participants: } \\
\text { - Read the books and } \\
\text { discuss the verbs or } \\
\text { adjectives used to } \\
\text { describe the material } \\
\text { - Discuss some } \\
\text { vocabulary or key words } \\
\text { that are used in } \\
\text { describing products } \\
\text { - Each participant asks } \\
\text { questions and responds } \\
\text { to questions after } \\
\text { describing the things }\end{array}$ \\
\hline
\end{tabular}




\section{Session 5:}

\begin{tabular}{|c|c|c|c|c|}
\hline $\begin{array}{c}\text { Time } \\
\text { allotment }\end{array}$ & $\begin{array}{l}\text { Topic / } \\
\text { content }\end{array}$ & $\begin{array}{l}\text { Learning } \\
\text { outcomes }\end{array}$ & $\begin{array}{l}\text { Language } \\
\text { components }\end{array}$ & Class activities \\
\hline 2 hours & $\begin{array}{l}\text { 1.Comparing } \\
\text { one thing to } \\
\text { another thing }\end{array}$ & $\begin{array}{l}\text { Structure: } \\
\text { Participants are } \\
\text { able to: } \\
\text { - understand the } \\
\text { comparative } \\
\text { degree } \\
\text { - distinguish } \\
\text { adjective, } \\
\text { comparative, } \\
\text { and superlative } \\
\text { forms } \\
\text { Vocabulary: } \\
\text { Participants are } \\
\text { able to use some } \\
\text { adjectives, noun } \\
\text { and adverbs that } \\
\text { are often found in } \\
\text { a product catalog } \\
\text { Speaking: } \\
\text { Participants are } \\
\text { able to: } \\
\text { - use correct } \\
\text { tenses in a } \\
\text { conversation. } \\
\text { - use adjectives } \\
\text { in their } \\
\text { sentences. } \\
\text { - compare one of } \\
\text { the things to } \\
\text { another things }\end{array}$ & $\begin{array}{l}\text { - The forms of } \\
\text { adjective, } \\
\text { comparative, } \\
\text { and } \\
\text { superlative. } \\
\text { Examples: } \\
\text { Adjective } \\
\text { - profitable } \\
\text { - high } \\
\text { - low } \\
\text { - new } \\
\text { - old } \\
\text { - expensive } \\
\text {-good } \\
\text { Comparative: } \\
\text { - higher } \\
\text { - lower } \\
\text { - better } \\
\text { - cheaper } \\
\text { - thiner } \\
\text { Superlative: } \\
\text { - the most } \\
\text { expensive } \\
\text { - the cheapest } \\
\text { - the biggest } \\
\text { - the heaviest } \\
\text { - the thinest } \\
\text { Words that are } \\
\text { often found in } \\
\text { product } \\
\text { catalogues }\end{array}$ & $\begin{array}{l}\text { Teacher: } \\
\text { - Shows different things } \\
\text { and explains the } \\
\text { comparative, } \\
\text { superlative by using } \\
\text { pictures } \\
\text { - Asks participants to do } \\
\text { a group discussion and } \\
\text { asks them to discuss the } \\
\text { strengths and weakness } \\
\text { of their products. } \\
\text { - Gives vocabulary } \\
\text { exercises } \\
\text { Participants: } \\
\text { - will see animal, fruit, } \\
\text { hobby, place pictures } \\
\text { shown on slides and } \\
\text { then they describe the } \\
\text { features of these items. } \\
\text { - describe the things by } \\
\text { using correct } \\
\text { comparative forms. } \\
\text { - do a group discussion to } \\
\text { describe the differences } \\
\text { between the products } \\
\text { and also describe their } \\
\text { strengths and } \\
\text { weaknesses } \\
\text { - do a vocabulary } \\
\text { exercise: find the } \\
\text { meanings of the } \\
\text { difficult words and } \\
\text { match the words with } \\
\text { the right pictures }\end{array}$ \\
\hline
\end{tabular}




\section{Session 6:}

\begin{tabular}{|c|c|c|c|c|}
\hline $\begin{array}{c}\text { Time } \\
\text { allotment }\end{array}$ & $\begin{array}{l}\text { Topic / } \\
\text { content }\end{array}$ & $\begin{array}{l}\text { Learning } \\
\text { outcomes }\end{array}$ & $\begin{array}{c}\text { Language } \\
\text { components }\end{array}$ & Class activities \\
\hline 2 hours & $\begin{array}{l}\text { 1.Dealing with } \\
\text { number of } \\
\text { things such } \\
\text { as (in } \\
\text { previous } \\
\text { lessons), } \\
\text { noun and } \\
\text { adjective }\end{array}$ & $\begin{array}{l}\text { Structure: } \\
\text { Participants are } \\
\text { able to: } \\
\text { - identify ordinal } \\
\text { and cardinal } \\
\text { numbers } \\
\text { - recognize and } \\
\text { comprehend the } \\
\text { amount of } \\
\text { money } \\
\text { Vocabulary: } \\
\text { Participants are } \\
\text { able to use } \\
\text { vocabulary } \\
\text { related to order } \\
\text { quantity } \\
\text { Speaking: } \\
\text { Participants are } \\
\text { able to: } \\
\text { - explain the } \\
\text { number } \\
\text { - use ordinal and } \\
\text { cardinal } \\
\text { numbers in } \\
\text { speaking } \\
\text { correctly } \\
\text { Listening: } \\
\text { Participants are } \\
\text { able to: } \\
\text { respond or answer } \\
\text { the customers' } \\
\text { questions about } \\
\text { the numbers and } \\
\text { letter }\end{array}$ & $\begin{array}{l}\text { - Cardinal and } \\
\text { ordinal } \\
\text { numbers } \\
\text { Examples: } \\
\text { - there are } \\
\text { seven toys }\end{array}$ & $\begin{array}{l}\text { Teacher: } \\
\text { - Explains about cardinal } \\
\text { and ordinal numbers } \\
\text { - Plays a cassette about } \\
\text { numbers and asks } \\
\text { participants to listen } \\
\text { carefully, and then asks } \\
\text { them to practice to } \\
\text { pronounce the words } \\
\text { - Shows the pictures and } \\
\text { the sound, then ask } \\
\text { participants to } \\
\text { pronounce the pictures } \\
\text { - Asks participants to do } \\
\text { a role play, act as a } \\
\text { teacher who explains } \\
\text { the nouns to a student } \\
\text { who asks for the what } \\
\text { the the thing is } \\
\text { Participants: } \\
\text { - practice pronouncing } \\
\text { the numbers, amount of } \\
\text { profession, animal, } \\
\text { number }\end{array}$ \\
\hline
\end{tabular}

\section{Session 7:}

\begin{tabular}{|c|c|c|c|c|}
\hline $\begin{array}{c}\text { Time } \\
\text { allotment }\end{array}$ & $\begin{array}{l}\text { Topic / } \\
\text { content }\end{array}$ & $\begin{array}{l}\text { Learning } \\
\text { outcomes }\end{array}$ & $\begin{array}{l}\text { Language } \\
\text { components }\end{array}$ & Class activities \\
\hline 2 hours & 1.Greeting & $\begin{array}{l}\text { Structure: } \\
\text { Participants are } \\
\text { able to: } \\
\text { - Greet } \\
\text { - Respond } \\
\text { greeting } \\
\text { Participants are } \\
\text { able to: } \\
\text { - use proper } \\
\text { vocabulary } \\
\text { when talking to } \\
\text { students }\end{array}$ & $\begin{array}{l}\text { - Confirmation/ } \\
\text { tag questions } \\
\text { words (aren't, } \\
\text { isn't) } \\
\text { - Introducing } \\
\text { modals such: } \\
\text {-can/ could } \\
\text {-should } \\
\text {-may/ might } \\
\text {-must } \\
\text {-shall/ shall } \\
\text { - Vocabulary for }\end{array}$ & $\begin{array}{l}\text { Teacher: } \\
\text { - Explains the } \\
\text { confirmation form/ tag } \\
\text { questions } \\
\text { - Introduces modals } \\
\text { - Plays a cassette about } \\
\text { conversation and asks } \\
\text { participant to explain } \\
\text { what the conversation } \\
\text { is about } \\
\text { Participants: }\end{array}$ \\
\hline
\end{tabular}




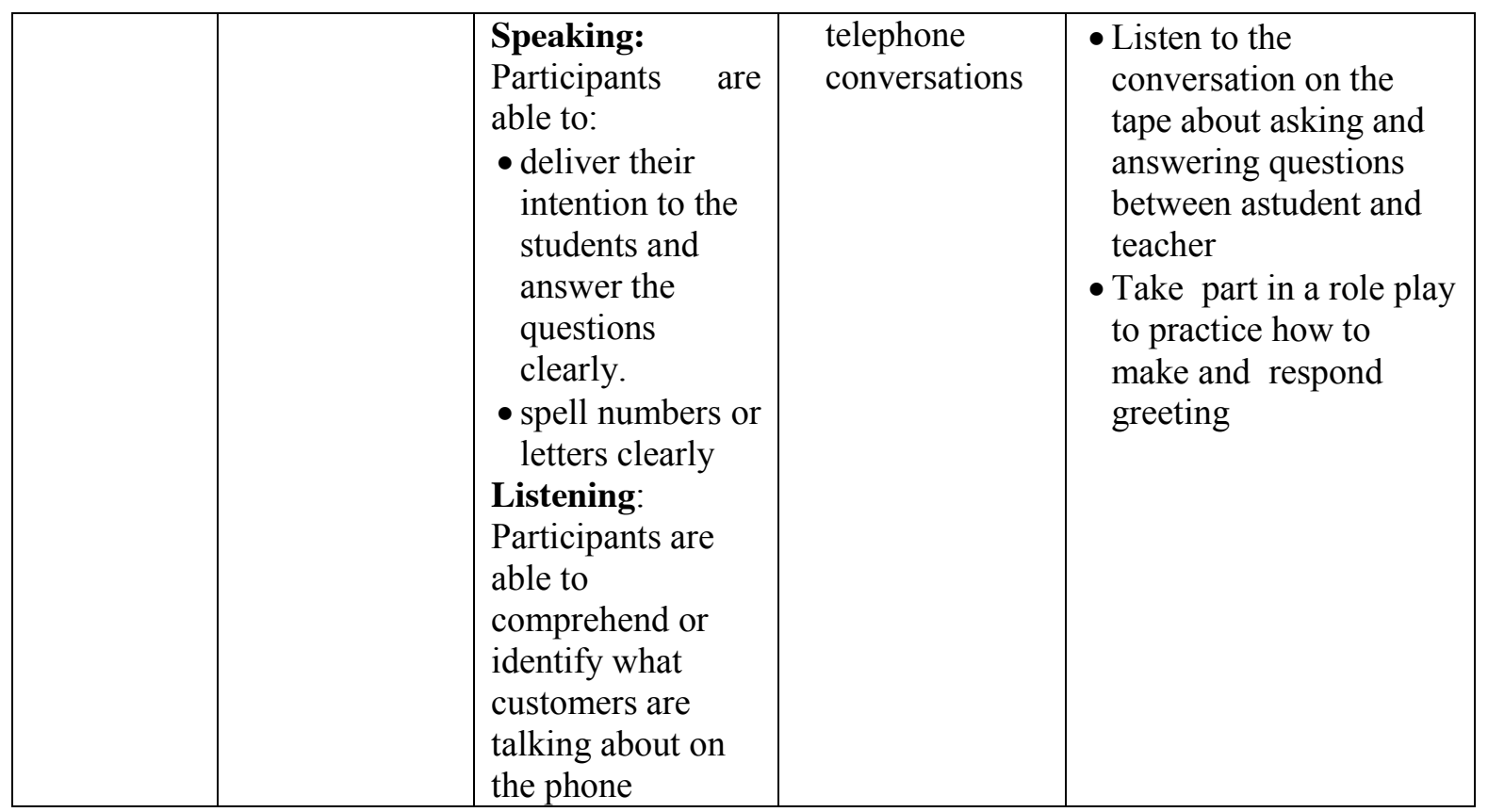

\section{Session 8:}

\begin{tabular}{|c|c|c|c|c|}
\hline $\begin{array}{c}\text { Time } \\
\text { allotment }\end{array}$ & $\begin{array}{c}\text { Topic / } \\
\text { content }\end{array}$ & $\begin{array}{l}\text { Learning } \\
\text { outcomes }\end{array}$ & $\begin{array}{c}\text { Language } \\
\text { components }\end{array}$ & Class activities \\
\hline 2 hours & 1.Reviewing & $\begin{array}{l}\text { Structure: } \\
\text { Participants are } \\
\text { able to: } \\
\text { - identify and use } \\
\text { present tense, } \\
\text { present } \\
\text { continoue } \\
\text { - use modals } \\
\text { forms correctly } \\
\text { and their } \\
\text { functions : } \\
\text {-can/ could/ } \\
\text { could not } \\
\text {-should/ should } \\
\text { not } \\
\text {-may/ might/ } \\
\text { may not/ might } \\
\text { not } \\
\text {-must/ must not } \\
\text {-shall/ shall not } \\
\text {-will/would/ } \\
\text { would not } \\
\text { Vocabulary: } \\
\text { Participants are } \\
\text { able to use } \\
\text { vocabularies } \\
\text { related to } \\
\text { greeting, } \\
\text { counting,explaini } \\
\text { ng animals, letter, } \\
\text { color, etc } \\
\text { Speaking: }\end{array}$ & $\begin{array}{l}\text { - Forms of } \\
\text { present tense } \\
\text { present } \\
\text { countinous } \\
\text { and future } \\
\text { - Forms of } \\
\text { modals } \\
\text { - Vocabulary } \\
\text { related to } \\
\text { number, letter, } \\
\text { occupation, } \\
\text { animal, fruit }\end{array}$ & $\begin{array}{l}\text { Teacher: } \\
\text { - Reviews the pattern of } \\
\text { tenses } \\
\text { - Explains forms of } \\
\text { modals } \\
\text { - Gives grammar and } \\
\text { vocabulary excercises. } \\
\text { The grammar excercises } \\
\text { focuses on present } \\
\text { tenses and continous } \\
\text { tense, and nouns } \\
\text { - Asks participants to do } \\
\text { a role play between a } \\
\text { teacher and student } \\
\text { about the subject had } \\
\text { given } \\
\text { Participants are able to: } \\
\text { - Make sentences in } \\
\text { correct tenses } \\
\text { - Teach the students with } \\
\text { the correct } \\
\text { pronounciation } \\
\text { - Teach the students how } \\
\text { to spell the words } \\
\text { - Teach the students how } \\
\text { to respond the } \\
\text { greetings. }\end{array}$ \\
\hline
\end{tabular}




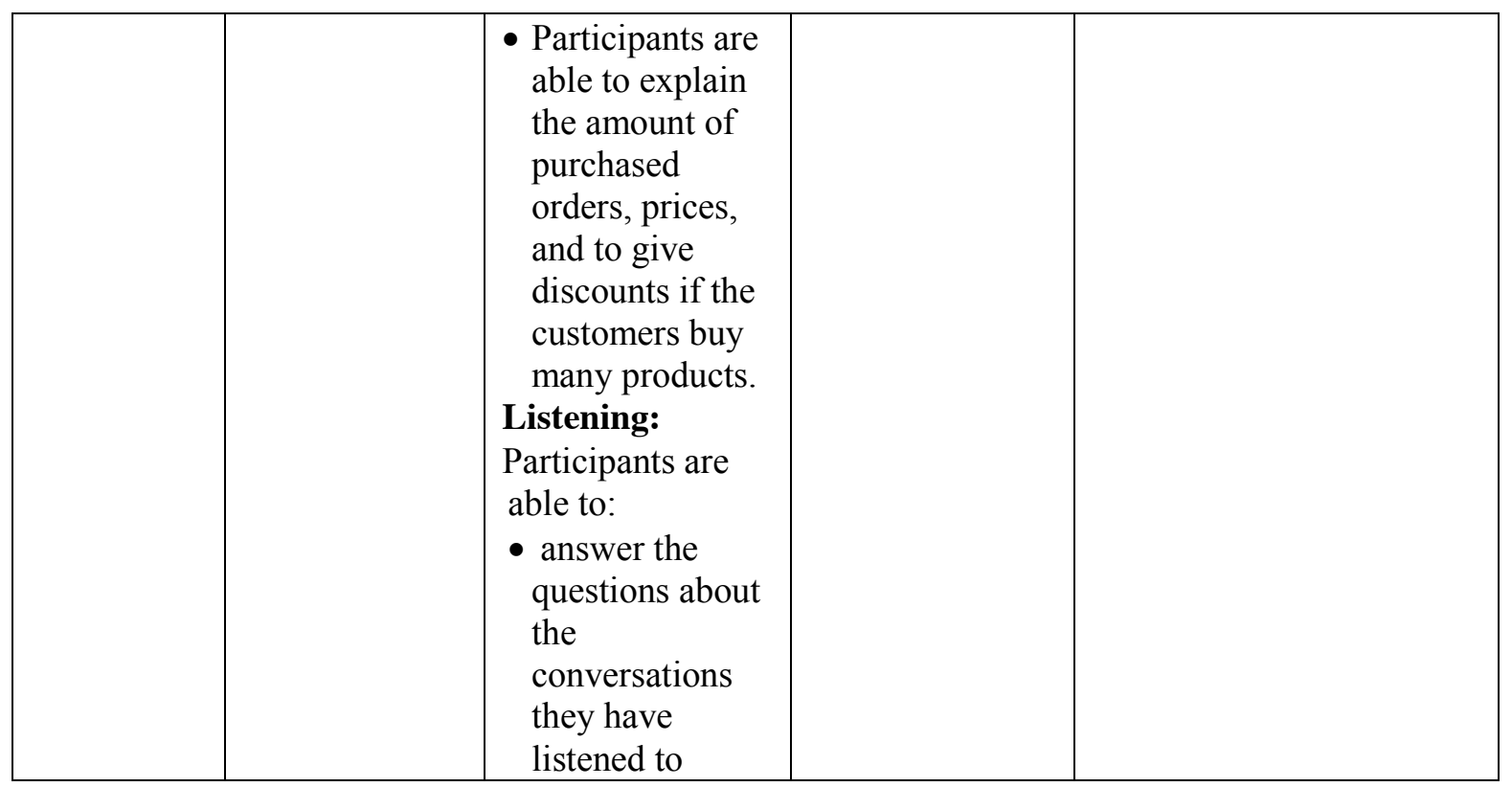

\section{CONCLUSION}

After analyzing the collected data, the writer comes to some conclusions of the study. Firstly, according to collected data, all teachers at biMBA AIUEO need to learn English to improve their English competencies because biMBA will open English class. The content in the syllabus are based on the participants' needs, so it will becomea fruitful syllabus. Thus, the teachers will attend the course enthusiasticly. Hopefully, the course will achieve the targets of the participants.

Secondly, most of the teachers have been working more than two years, they graduated from non English department, but they will be trained to teach English in biMBA. Therefore, English syllabus is necessary to design in order to fulfill their expectation after joining the course.

Thirdly, the contents of the syllabus focuses more on speaking, listening, and writing skills. The activities such as performing a role-play, watching video, drilling pronunciation, are used to develop the participants' competencies.

\section{REFERENCES}

Basturkmen, H. (2006). Ideas and Options in English for Specific Purposes. New Jersey: Lawrence Earlbaum Associates, Inc.

Celce-Murcia, M. (2001). Language teaching approaches: An overview. In M. Celce-Murcia (ed.), Teaching English as a Second or Foreign Language (pp. 3-11). Boston: Heinle \& Heinle.

Chew, K.-S. (2005). An investigation of the English language skills used by new entrants in banks in Hong Kong. English for Specific Purposes, an International Journal, 1, 423-435.

Corner, M. (2004). Andragogy and Pedagogy. Retrieved from http://www.agelesslearner.com/intros /andragogy.html

Crystal, D. (1997). English as a global language. First edition. Cambridge: Cambridge University Press.

Dudley-Evans, T., \& St John, M. J. (1998). Developments in English for Specific Purposes. Cambridge: Cambridge University Press.

Douglas, D. (2000). Assessing languages for specific purposes. Cambridge: Cambridge University Press.

Dudley-Evans, T. \& St. John, M.J. (1998). Developments in English for specific purposes. Cambridge: Cambridge University Press. 
Ellis, C. \& Johnson, M. (1994). Teaching business English. Oxford:Oxford University Press.

Farrel, T. S., \& Jacobs, G. M. (2010). Essentials for Successful English Language Teaching. London: Continuum International Publishing Group.

Graves, K. (1996). Teachers as course developers. Cambridge: Cambridge University Press.

Graves, K. (2002). Designing languagecCourses: A guide for teachers. Boston, MA: Heinle \& Heinle.

Hoekje, B. J. (2007). Medical Discoruse and ESP courses for International Medical Graduates (IMGs). English for Specific Purposes, an International Journal , 26 (3).

Hutchinson, T., \& Waters, A. G. (1987). English for Specific Purposes a learning-centered approach. Cambridge: Cambridge University Press. 